\title{
Effects of Dietary Cholestyramine on Growth and Protein Utilization of Chicks Given Diets Containing Medium or Long Chain Triacylglycerols
}

\author{
Remedios T. Mabayo, Jun-Ichi Okumura and Mitsuhiro Furuse \\ Laboratory of Animal Nutrition, School of Agricultural Sciences, \\ Nagoya University, Nagoya 464-01
}

\begin{abstract}
The effects of graded levels of cholestyramine (CSTY, a bile acid binding polymer), which prevents micelle formation and bile acid reabsorption, on growth and protein utilization of chicks given diets containing different dietary concentrations of medium chain triacylglycerol (MCT) and long chain triacylglycerol (LCT) were investigated. MCT or LCT diets at 100 or $200 \mathrm{~g}$ oil $/ \mathrm{kg}$ diet containing 0,10 or $20 \mathrm{~g} \mathrm{CSTY} / \mathrm{kg}$ were freely fed to $7 \mathrm{~d}$ old chicks for $10 \mathrm{~d}$. Dietary metabolizable energy value of diets without CSTY used in the present study were much higher than the recommended by NRC (1994). Body weight gain was reduced by increasing dietary levels of MCT, but not LCT. The addition of CSTY reduced body weight gain, but did not affect protein retention of chicks fed the MCT or LCT diets.
\end{abstract}

(Jpn. Poult. Sci., $34:$ 333-338, 1997)

Key words : chick growth, cholestyramine, medium chain triacylglycerol, long chain triacylglycerol, protein utilization

\section{Introduction}

Medium chain triacylglycerols (MCT) are absorbed and metabolized differently from long chain triacylglycerols (LCT) in mammals. According to GREENBERGER et al. (1966), MCT can be hydrolyzed to medium chain fatty acid (MCFA) and glycerol in the lumen at decreased concentration of pancreatic enzymes. The path for the transport of MCFA is both through the portal vein and lymph, but the corresponding long chain fatty acid (LCFA) is transported entirely by the lymph (ВLоOм et al., 1951). In turn, LCFA forms mixed micelles with bile acids, although MCFA is well absorbed in the absence of bile acids (GARRET and Young, 1975). After transport to the liver, MCFA is quickly oxidized and is not incorporated in the lipid ester moieties of lipoproteins (HASHIM and TANTIBHEDYANGKUL, 1987), consequently body fat deposition is lower on the MCT than on the LCT diets. Because the functional intestinal lymphatic system is absent in birds (ANNISON, 1983), both MCFA and LCFA are transported to the liver, which being largely different from the mammal. The absorbed energy from LCT is accumulated efficiently as fat in the body, compared with that from MCT (FURUSE et al.,

Received January 20, 1997 Accepted March 25, 1997

Correspondence should be addressed to : Dr. M. Furuse, Laboratory of Animal Feed Science, Faculty of Agriculture, Kyushu University, Fukuoka 812-81, Japan Tel. (092) 642-2953 Fax (092) 642-2953 E-Mail furuse@agr.kyushu-u.ac.jp 
1992 b ; MABAYO et al., 1993, 1994). Unique attributes of MCT were reported that MCT increased liver protein synthesis in chicks (KITA et al., 1993).

According to МАвА Yo et al. (1994), linoleic acid is well absorbed even in high concentration, but the absorption of octanoic acid is poor when given in high concentration in chicks. This result implies that octanoic acid is not simply absorbed as observed in rats (GARRET and YounG, 1975). Cholestyramine (CSTY), a bile acid binding polymer, binds to bile acids in the intestinal lumen, thereby enhancing their excretion. The administration of CSTY may interfere with micelle formation, and so it could be a good tool for studies related to bile acids. Our recent study suggested that CSTY reduced the utilization of dietary MCT in chicks (MABAYo et al., 1995). There is no report, however, as to what degree CSTY will affect the utilization of dietary protein given at a certain level.

This study, therefore, aims to investigate whether growth and protein utilization of chickens given diets containing different dietary concentration of MCT and LCT are altered by adding different levels of CSTY.

\section{Materials and Methods}

One-day-old Single Comb White Leghorn male chicks were given a commercial starter diet (Marubeni Shiryo Ltd., Tokyo) containing of $215 \mathrm{~g}$ crude protein $(\mathrm{CP}) / \mathrm{kg}$ and $12.1 \mathrm{~kJ} / \mathrm{g}$ metabolizable energy (ME), for $7 \mathrm{~d}$. On day 8 , the chicks were individually weighed after overnight deprivation of food, and were divided into 13 groups of 5 chicks each, so that mean body weights per group were as uniform as possible. The chicks in the 13th group were killed by cervical dislocation and used to determine base values. The remaining 12 groups were individually housed in stainless-steel metabolism cages and fed ad libitum experimental diets from day 8 to 17 .

Table 1 shows the composition of experimental CSTY free diets. Corn oil was used as the LCT source and Coconado $\mathrm{RK}^{\circledR}$ (glyceryl tricaprylate, donated by Kao Corporation, Wakayama) was used as the MCT source. Corn oil was added to the MCT diet to meet the requirement of linoleic acid. The diets of MCT or LCT at 100 or $200 \mathrm{~g}$ oil level contained 0,10 or $20 \mathrm{~g} \mathrm{CSTY} / \mathrm{kg}$ diet. Questran ${ }^{\circledR}$ (contains $444 \mathrm{~g} \mathrm{CSTY}$ / $\mathrm{kg}$; Bristol-Myers K.K., Tokyo) was included in the diet replacing equal amount of corn starch. Other constituents of Questran ${ }^{\circledR}$ are mostly glucose. For each oil level set, 22.5 or $45 \mathrm{~g}$ of Questran ${ }^{\circledR} / \mathrm{kg}$ diet was included to supply 10 or $20 \mathrm{~g} \mathrm{CSTY} / \mathrm{kg}$ to the MCT or LCT diet. Calculated CP contents in all experimental diets were $200 \mathrm{~g} / \mathrm{kg}$ diet. Calculated ME values of CSTY free diets were 14.4 and $14.9 \mathrm{~kJ} / \mathrm{g}$ for $100 \mathrm{~g}$ MCT and LCT diets respectively, 15.9 and $17.2 \mathrm{~kJ} / \mathrm{g}$ for $200 \mathrm{~g}$ MCT and LCT diets respectively. ME of LCT was taken to be $36.5 \mathrm{~kJ} / \mathrm{g}$ (ScotT et al., 1982) and MCT source was $30.7 \mathrm{~kJ} /$ $\mathrm{g}$ (Furuse et al., $1992 \mathrm{~b}$ ). The chicks were killed by decapitation on day 18 . The carcass was minced with a meat grinder. The minced samples were frozen in liquid nitrogen, minced twice and dried at $55^{\circ} \mathrm{C}$ for $48 \mathrm{~h}$. Nitrogen $(\mathrm{N})$ in the diets and carcasses was determined by the Kjeldahl method and CP was calculated as $\mathrm{N} \times 6.25$. Gains in protein over the experimental period were determined by subtracting values for the initial body composition from the final experimental ones. 
Table 1. Composition of cholestyramine free diets $(\mathrm{g} / \mathrm{kg})$

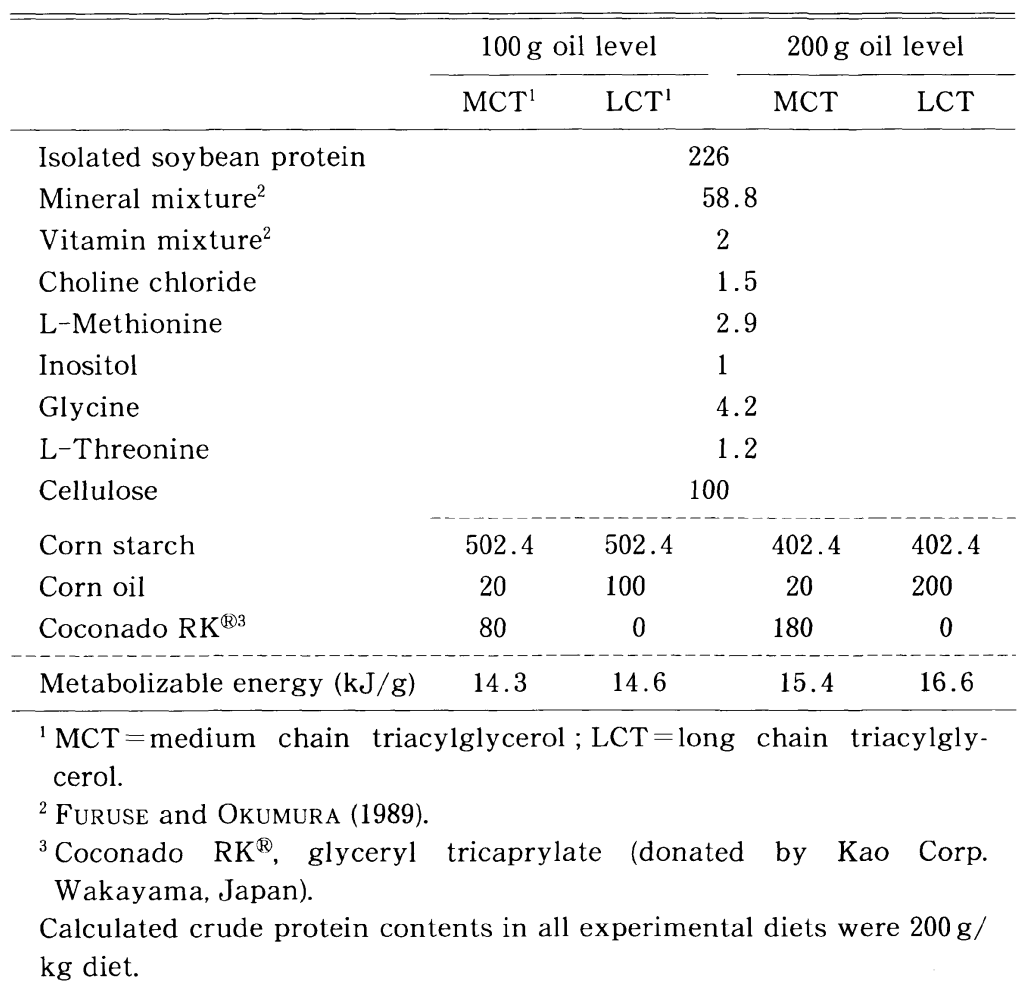

Data were subjected to three way analysis of variance by using a commercially available statistical package (SAS, 1985).

\section{Results}

Body weight gain and food intake of chicks given diets containing MCT or LCT at 100 or $200 \mathrm{~g}$ oil level containing 0,10 or $20 \mathrm{~g} \mathrm{CSTY} / \mathrm{kg}$ are shown in Fig. 1 . Body weight gain was reduced by increasing levels of MCT in the diet, but was not affected in chicks fed the LCT diet. The addition of CSTY reduced body weight gain of chicks fed MCT or LCT diet. Food intake of chicks given the MCT diet decreased as oil level increased, but was not affected in chicks given LCT diet. The group given $200 \mathrm{~g}$ MCT diet had the significantly lowest food intake, while the group given $200 \mathrm{~g}$ LCT diet and $20 \mathrm{~g}$ CSTY had the significantly highest food intake among treatments. Food efficiency of chicks given the LCT diet was reduced by CSTY, but the effect was lesser in chicks given MCT diet (data not shown).

Protein retention of chicks given diets containing MCT or LCT at 100 or $200 \mathrm{~g}$ oil level containing 0,10 or $20 \mathrm{~g} \mathrm{CSTY} / \mathrm{kg}$ diet is shown in Fig. 2. Protein retention was decreased by increasing oil level in chicks fed the MCT diet, but was not altered in chicks given LCT diet. No significant effect of CSTY was observed in protein retention. Efficiency of protein utilization (protein retained/protein consumed) was not affected by CSTY, but was increased in chicks given MCT diet (Fig. 2). 



Fig. 1. Effects of cholestyramine on body weight gain and food intake of chicks fed diets containing medium chain triacylglycerol (MCT) or long chain triacylglycerol (LCT) at 100 or $200 \mathrm{~g}$ oil/ $\mathrm{kg}$ diet.

Values are means for 5 birds. Details in triacylglycerol sources are given in Table 1.

Results of analysis of variance

Body weight gain Food intake

Main effects :

Oil level (OL)

Cholestyramine

level (CSTY)

Oil source (OS)

Interaction :

$\begin{array}{lcc}\text { OL } \times \text { CSTY } & \text { NS } & \text { NS } \\ \text { CSTY } \times \text { OS } & \text { NS } & * * * \\ \text { OL } \times \text { OS } & * * * & * * * \\ \text { OL } \times \text { OS } \times \text { CSTY } & \text { NS } & *\end{array}$

**** Significantly different at $\mathrm{P}<0.05$ and $\mathrm{P}<$ 0.001 , respectively. NS : Not significant.
Fig. 2. Effects of cholestyramine on protein retention and efficiency of protein utilization (EPU, protein retained/protein consumed) of chicks fed diets containing medium chain triacylglycerol (MCT) or long chain triacylglycerol (LCT) at 100 or $200 \mathrm{~g}$ oil $/ \mathrm{kg}$ diet.

Values are mean for 5 birds. Detainls in triacylglycerol sources are given in Table 1.

Results of analysis of variance

$\begin{array}{lcc}\text { Main effects : } & \text { Protein } & \text { EPU } \\ \text { Oil level (OL) } & & \\ \begin{array}{l}\text { Cholestyramine level } \\ \text { (CSTY) }\end{array} & \mathrm{NS} & \mathrm{NS} \\ \quad \text { Oil source (OS) } & * * * & \\ \text { Interaction : } & & \\ \text { OL } \times \text { CSTY } & \mathrm{NS} & \mathrm{NS} \\ \text { CSTY } \times \text { OS } & \mathrm{NS} & \mathrm{NS} \\ \text { OL } \times \text { OS } & * & \mathrm{NS} \\ \text { OL } \times \text { OS } \times \text { CSTY } & \mathrm{NS} & \mathrm{NS}\end{array}$

${ }^{*}, * * * * * *$ Significantly different at $\mathrm{P}<0.05, \mathrm{P}<0.01$ and $\mathrm{P}<0.001$, respectively. NS : Not significant. 


\section{Discussion}

CSTY is an anion exchange polymer which irreversibly binds intraluminal bile acids as well as other components of normal luminal micelles, including phospholipid, monoacylglycerol, fatty acid and cholesterol (VAHOUnY et al., 1980). It was confirmed in the present study that CSTY generally affected growth, but not protein retention in the chicks.

In chicks given the LCT diet, body weight gain was not altered by changing oil level, since food intake was not depressed, but it increased at $200 \mathrm{~g}$ oil level with $20 \mathrm{~g}$ $\mathrm{CSTY} / \mathrm{kg}$ diet. This result was consistent with the results by KeELA and ThOMson's report (1991) that food intake was higher in rats fed CSTY with less body weight change. The increased food intake of chicks given dietary LCT with $20 \mathrm{~g} \mathrm{CSTY} / \mathrm{kg}$ could be accounted to the changes in protein : energy ratio. The high concentration of fat in the diet consequently increased the $\mathrm{ME}$ to much higher level than the requirement (NRC, 1994). Hence, protein : energy ratio was low. The addition of CSTY brought about the excretion of fat (MABAYo et al., 1995) ; thus, protein : energy ratio was increased and consequently food intake was improved. Under ad libitum conditions, MCT decreased food intake of chicks (FuRUSE et al., 1992 b, 1993) and rats (Furuse et al., 1992 a). In the present study, these observations were reconfirmed. Dietary MCT has been shown to increase efficiency of protein utilization in chicks (Furuse et al., 1992 b, MABAyo et al., 1993) as confirmed in this study. On the other hand, CSTY did not influence both protein retention and efficiency of protein utilization. This could be explained by dietary ME value, because the diet containing much oil could supply enough ME to meet the requirement even under $20 \mathrm{~g} \mathrm{CSTY} / \mathrm{kg} \operatorname{diet}$ (FURUSE et al., 1997).

\section{References}

Annison, E.F. (1983) Lipid Metabolism, in : Freeman, B.M. (ed.) Physiology and Biochemistry of Domestic Fowl, Vol. 4. pp. 165-174. Academic Press, London.

Bloom, B.I., ChAIKoff, L.L. and ReinhaRdT, W.O. (1951) Intestinal lymph as pathway for transport of absorbed fatty acids of different chain lengths. American Journal of Physiology, 166 : 451 -455 .

Furuse, M., Chol, Y.-H., Mabayo, R.T., Denbow, M. and Okumura, J. (1992 a) Feeding behavior in rats fed diets containing medium chain triglyceride. Physiology and Behavior, 52 : 815-817.

Furuse, M., Mabayo, R.T., Choi, Y.-H. and Okumura, J. (1993) Feeding behavior in chicks given diets containing medium chain triglyceride. British Poultry Science, 34 : 211-217.

Furuse, M., Mabayo, R.T., Kita, K. and Okumura, J. (1992 b) Effects of dietary medium chain triglycerides on protein and energy utilisation of chicks. British Poultry Science, 33 : 39-47.

Furuse, M., Mabayo, R. T. and Okumura, J. (1997). Effects of dietary cholestyramine on the utilisation of diets containing medium or long chain triacylglycerol in chicks. British Poultry Science, in press.

Furuse, M. and OKumura, J. (1989) Effect of dietary acetic acid levels on protein and energy utilization in chicks. Poultry Science, 68 : 795-798.

GARRET, R.L. and YounG, J.R. (1975) Effect of micelle formation on the absorption of neutral fat and fatty acids by the chicken. Journal of Nutrition, $105: 827-838$.

GREENBERger, N.J,. Rodgers, J.B. and IsEelbacher, K.J. (1966) Absorption of medium and long chain triglycerides : factors influencing their hydrolysis and transport. Journal of Clinical 
Investigation, $45: 217-227$.

Hashim, S.A. and Tantibhedyangkul, P. (1987) MCT in early life : effects on growth of adipose tissue. Lipids, $22: 429-434$.

Keelan, M. and Thomson, A.B.R. (1991) Feeding diets containing 2\% cheno- or urso-deoxycholic acid or cholestyramine to rats for two weeks alters intestinal morphology and bile acid absorption. Canadian Journal of Physiology and Pharmacology, 69 : 592-598.

Kita, K., Mabayo, R.T., Furuse, M. and Okumura, J. (1993) Dietary medium chain triglyceride increases liver protein synthesis in chicks. Asian-Australasian Journal Animal Science, 6 : 339-342.

Mabayo, R.T., Furuse, M., Kita, K. and OkumuRa, J. (1993) Improvement of dietary protein utilisation by medium chain triglyceride. British Poultry Science, 34 : 121-130.

Mabayo, R.T., Furuse, M., Murai, A. and Okumura, J. (1994) Interactions between medium chain and long chain triacylglycerols in the lipid and energy metabolism in growing chicks. Lipids, 29 : 139-144.

Mabayo, R.T., Furuse, M., Murai, A. and Okumura, J. (1995) Cholestyramine alters the lipid and energy metabolism of chicks fed dietary medium or long chain triacylglycerol. Lipids, 30 : 839-845.

National Research Council (1994) Nutrient Requirements of Poultry, 9th rev. ed. National Academy Press, Washington, DC.

SAS Institute Inc. (1985) SAS User's Guide : Statistics, version 5 ed. Cary NC.

ScotT, M.L., Nesheim, M.C. and Young, R.J. (1982) Nutrition of the Chicken. 3rd ed. M. L. Scott and Associates, Ithaca, NY.

Vahouny, G.V., Tombes, R., CAssidy, M.M., KRithchevsky, D. and Gallo, L. (1980) Dietary fibers : V. Binding of bile salts, phospholipids and cholesterol from mixed micelles by bile acid sequestrants and dietary fibers. Lipids, 15 : 1018-1021.

\title{
中鎖脂肪あるいは長鎖脂肪を含む飼料を給与したニワトリヒナの 成長と蛋白質の利用性に及ぼす飼料コレスチラミンの効果
}

\author{
レメジョス T. マバョ・奥村純市・古瀬充宏 \\ 名古屋大学農学部，名古屋市千種区 464-01
}

\footnotetext{
中鎖脂肪 (MCT) あるいは長鎖脂肪 (LCT) 含量の異 なる飼料にミセルの形成之胆汁酸の再吸収を抑制する胆 汁酸結合ポリマーであるコレスチラミン (CSTY) を 様々な水準で添加した場合に二ワトリヒナの成長と蛋白 質の利用性がどのような影響を受けるかについて研究し た。MCT またはLCT の水準は飼料 $1 \mathrm{~kg}$ 当たり 100 あ るいは $200 \mathrm{~g}$ とし, 飼料中の CSTY の水準は 0,10 なら びに $20 \mathrm{~g} / \mathrm{kg}$ とした。飼料は 7 日齢のヒナに 10 日間自
}

由摂取させた。増体重は飼料中の MCT 含量が高まると 低下したが，LCTにおいてはそのような影響は認めら れなかった。CSTY の添加により MCT およびLCT 両 飼料において成長ならびに蛋白質の蓄積は低下した。

(家禽会誌, 34 : 333-338, 1997) キーワード：ヒナの成長，コレスチラミン，中銷脂肪， 長鎖脂肪，蛋白質蓄積 